\title{
Lightweight amorphous silicon photovoltaic modules on flexible plastic substrate ${ }^{1}$
}

\author{
Y. Vygranenko, A. Khosropour, R. Yang, A. Sazonov, A. Kosarev, A. Abramov, and E. Terukov
}

\begin{abstract}
Solar cells on lightweight and flexible substrates have advantages over glass- or wafer-based photovoltaic devices in both terrestrial and space applications. Here, we report on development of amorphous silicon thin film photovoltaic modules fabricated at maximum deposition temperature of $150^{\circ} \mathrm{C}$ on $100 \mu \mathrm{m}$ thick polyethylene-naphtalate plastic films. Each module of $10 \mathrm{~cm} \times 10 \mathrm{~cm}$ area consists of $72 \mathrm{a}-\mathrm{Si}: \mathrm{H} \mathrm{n}$-i-p rectangular structures with transparent conducting oxide top electrodes with Al fingers and metal back electrodes deposited through the shadow masks. Individual structures are connected in series forming eight rows with connection ports provided for external blocking diodes. The design optimization and device performance analysis are performed using a developed SPICE model.
\end{abstract}

PACS Nos.: 88.40.H, 88.40.fc, 88.40.jj.

Résumé : Les cellules solaires sur support léger et flexible ont des avantages sur les dispositifs photovoltaïques basés sur substrats de verre ou autre solide, et ce pour des utilisation terrestres et spatiales. Nous présentons ici le développement de modules photovoltaïques en films minces de silicium amorphe, fabriqués à une température maximale de dépôt de $150^{\circ} \mathrm{C}$ sur des films de plastique PEN de $100 \mu \mathrm{m}$ d'épaisseur. Chaque module de $10 \mathrm{~cm} \times 10 \mathrm{~cm}$ de surface contient 72 structures rectangulaires de a-Si : $\mathrm{H}$ n-i-p, avec des électrodes supérieures de TCO avec doigts d'Al et des électrodes arrières métalliques déposées par masque d'ombre. Les structures individuelles sont connectées en série pour former huit rangées avec ports de connexion destinés aux diodes de blocage externes. Le design et les performances du dispositif sont analysés et évalués en utilisant un modèle SPICE. [Traduit par la Rédaction]

\section{Introduction}

Flexible hydrogenated amorphous silicon (a-Si:H) solar cells on thin plastic substrates are of great interest for a wide variety of engineering applications [1]. Flexible devices can be installed on curved surfaces, they are less likely to be damaged by mechanical friction and vibrations, and are easier to install. These advantages could make it possible for mobile devices and various electric appliances to cover part of their power demand from solar energy. Even an integration of photovoltaics in clothes becomes a reality [2]. Also light weight photovoltaic (PV) modules on plastic foils are attractive for aerospace applications because of higher power-toweight ratio in comparison to common GaAs-based PV devices [3].

Two approaches are used to fabricate flexible a-Si:H PV modules. The first is the use of nontransparent substrates, such as metallic foils or heat-resisting plastic films to enable a thin-film deposition in a temperature regime of $220-300{ }^{\circ} \mathrm{C}$, which is considered optimal for a-Si:H [4]. The second approach is the use of low-cost polyethylene-naphtalate or polyethylene-teraphtalate substrates that require process temperatures not exceeding $150{ }^{\circ} \mathrm{C}$ [5-7]. In this case, the device performance is lower because of deteriorating electronic properties of a-Si:H. To date, the highest stable efficiency of $8.7 \%$ was reported for single junction a-Si:H cells on a textured plastic substrate [8].

This paper reports on a monolithic a-Si:H-based photovoltaic module utilizing $100 \mu \mathrm{m}$ thick polyethylene-naphtalate film as a substrate. Detailed description of the device design and fabrication steps is the starting point of this work. We present and discuss a two-dimensional model of the solar cell. This follows with the performance analysis of the PV module. Finally results of the study are summarized in the conclusion part.

\section{PV module design and fabrication}

Figure $1 a$ shows a photograph of the developed PV module. The module of $10 \mathrm{~cm} \times 10 \mathrm{~cm}$ area consists of 72 rectangular cells. The individual cells are connected in series forming eight rows with connection pads. Figure $1 b$ shows the electrical circuit diagram, where the sections of 18 cells are connected in parallel using external blocking diodes. The cell design and its interconnections are illustrated in Figs. $1 c$ and $1 d$. The cell is an a-Si:H n-i-p structure with the $\mathrm{Al} / \mathrm{Cr}$ back and $\mathrm{ZnO}: \mathrm{Al}$ top electrodes. Two $0.3 \mathrm{~mm}$ wide $\mathrm{Al}$ fingers are symmetrically placed on the $\mathrm{ZnO}$ :Al electrode to reduce the emitter resistance. The photosensitive area of the cell is $0.8 \mathrm{~cm}^{2}$.

We have developed a fabrication process, where three shadow masks are used in sputtering steps to form the bottom and top electrodes and the top metallization. The device fabrication starts with plastic foils cleaned in an isopropanol bath for about $1 \mathrm{~min}$. After drying, the backside encapsulation and front buffer $\mathrm{SiO}_{x} \mathrm{~N}_{y}$ layers are deposited in the single-chamber plasma-enhanced chemical vapor deposition (PECVD) system at the substrate tem-

Received 15 October 2013. Accepted 21 January 2014.

Y. Vygranenko. Department of Electronics, Telecommunications and Computer Engineering, ISEL, Lisbon, 1959-007, Portugal; CTS-UNINOVA, 2829-516 Caparica, Portugal.

A. Khosropour, R. Yang, and A. Sazonov. Electrical and Computer Engineering Department, University of Waterloo, Waterloo, ON N2L 3G1, Canada.

A. Kosarev. National Institute for Astrophysics, Optics and Electronics, Puebla 72840, Mexico; TF TE Ioffe R\&D Center, St-Petersburg, Russia.

A. Abramov and E. Terukov. TF TE Ioffe R\&D Center, St-Petersburg, Russia.

Corresponding author: Y. Vygranenko (e-mail: yvygranenko@deetc.isel.ipl.pt).

${ }^{1}$ This paper was presented at the 25th International Conference on Amorphous and Nanocrystalline Semiconductors (ICANS25). 
Fig. 1. (a) Photograph of the PV module. (b) Circuitry of the PV module with external blocking diodes. (c) Top view of two cells connected in series. (d) Cross-sectional view of the cells.

a)

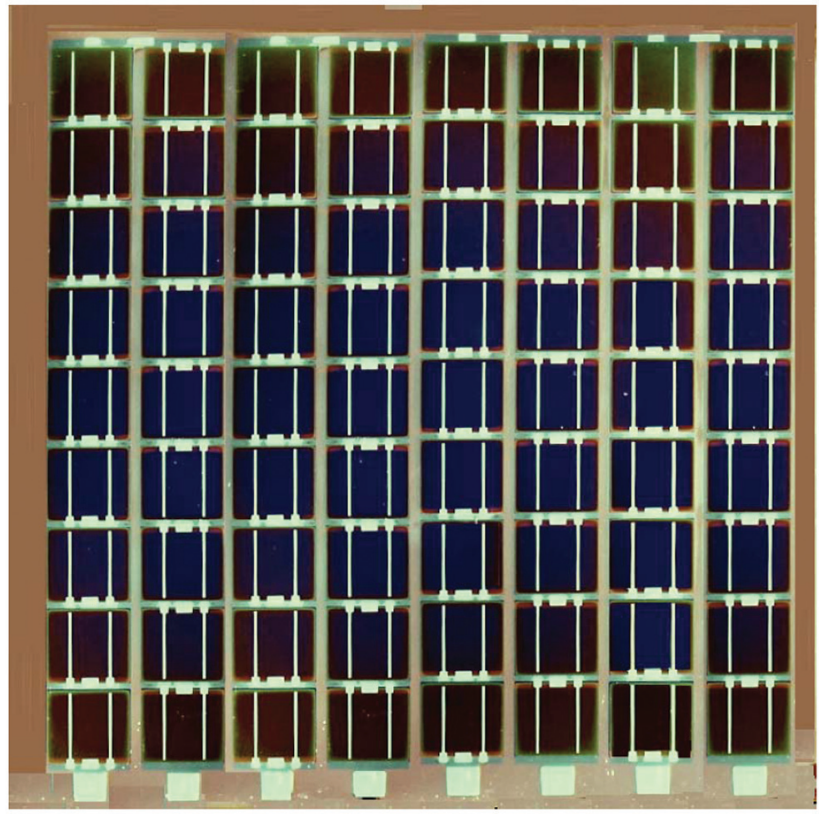

c)

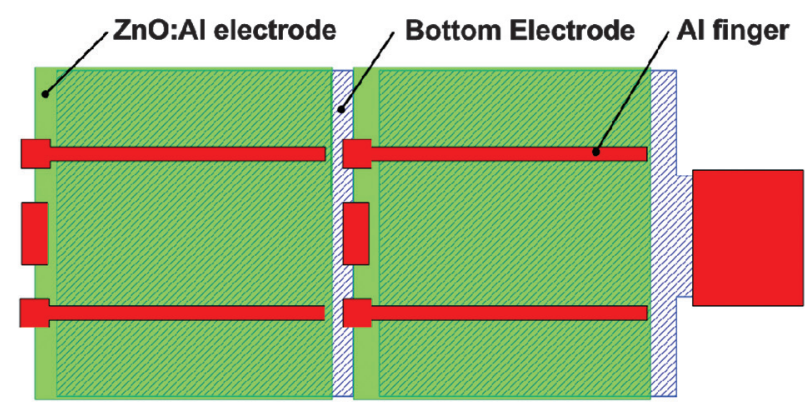

b)

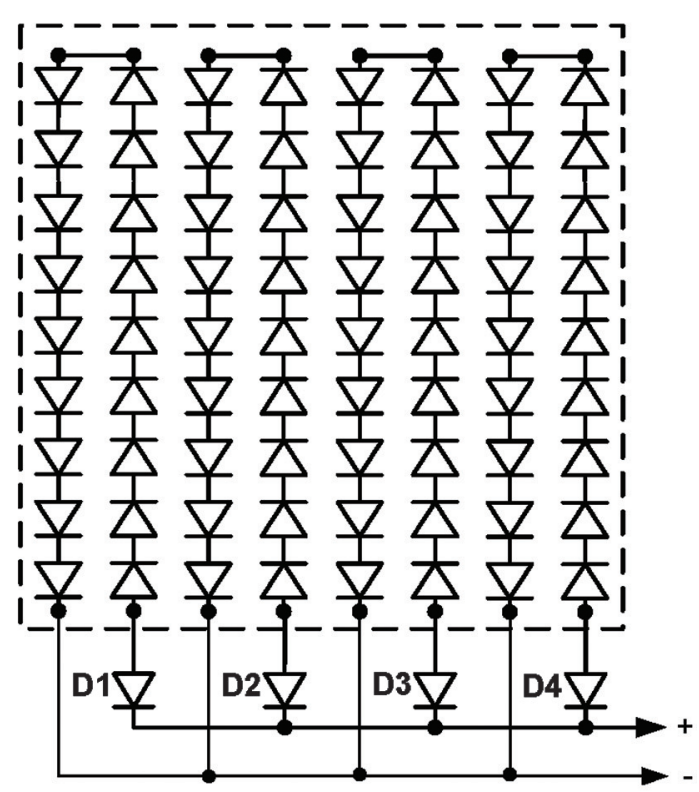

d)

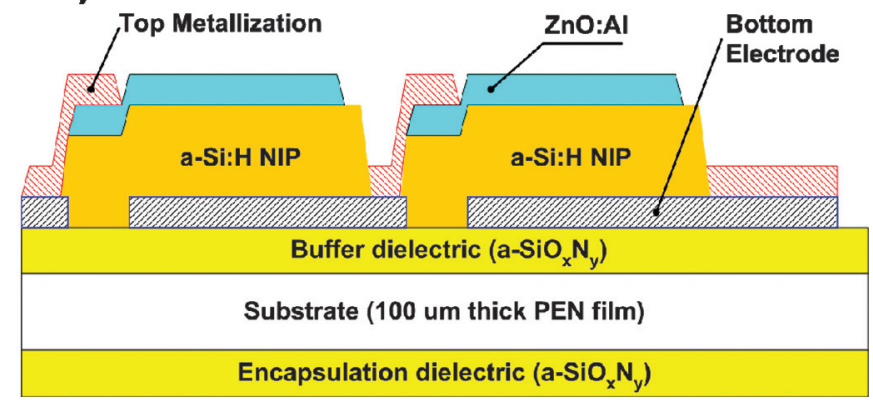

perature of $\sim 140{ }^{\circ} \mathrm{C}$. Then, the substrate in conjunction with shadow mask 1 is attached to the carrier followed by loading in the sputtering system. After reaching a base pressure below $2 \times$ $10^{-6}$ Torr, $200 \mathrm{~nm}$ of $\mathrm{Al}$ is sputtered in Ar plasma at a process pressure of 5 mTorr. Then, a thin $(\sim 20 \mathrm{~nm}) \mathrm{Cr}$ buffer layer is deposited under similar process conditions.

The n-i-p stack deposition is performed using a multichamber 13.56 MHz PECVD system, manufactured by MVSystems Inc. To prevent cross contamination here, the doped and undoped layers are deposited in different chambers in the single-pump-down process. The $25 \mathrm{~nm}$ thick n-layer, $300 \mathrm{~nm}$ thick i-layer, and $15 \mathrm{~nm}$ thick p-layer are deposited using $\mathrm{SiH}_{4}+\mathrm{H}_{2}+\mathrm{PH}_{3}, \mathrm{SiH}_{4}+\mathrm{H}_{2}$, and $\mathrm{SiH}_{4}+\mathrm{H}_{2}+\mathrm{CH}_{4}+\mathrm{B}_{2} \mathrm{H}_{6}$ gas mixtures, respectively. Here, hydrogen dilution ratio, [H2] / ([H2] $+[\mathrm{SiH} 4]) \times 100 \%$, is $75 \%$. Doping gas flow ratios are $\left[\mathrm{PH}_{3}\right] /\left[\mathrm{SiH}_{4}\right]=1 \%,\left[\mathrm{~B}_{2} \mathrm{H}_{6}\right] /\left[\mathrm{SiH}_{4}\right]=1 \%$, and $\left[\mathrm{CH}_{4}\right] /\left[\mathrm{SiH}_{4}\right]=$ $67 \%$. The deposition is performed at 600 mTorr pressure and $22 \mathrm{~mW} / \mathrm{cm}^{2}$ radio frequency power density. The substrate temperature is about $150{ }^{\circ} \mathrm{C}$.

The formation of $\mathrm{ZnO}: \mathrm{Al}$ top electrodes is performed by sputtering through shadow mask 2 in the sputtering chamber of the PECVD system. The $170 \mathrm{~nm}$ thick ZnO:Al layer is deposited in $\mathrm{Ar}$ plasma at $4 \mathrm{mTorr}$ pressure, $80 \mathrm{~W}$ radio frequency power, and
$150{ }^{\circ} \mathrm{C}$ substrate temperature. The sheet resistance of the film is about $60 \Omega /$ sq.

To perform via opening, the a-Si:H NIP stack is selectively etched through shadow mask 3 in the reactive ion etching system. Dry etching is performed in $\mathrm{SF}_{6}$ plasma at a process pressure of $60 \mathrm{mTorr}$, a gas flow of $15 \mathrm{sccm}$, and an radio frequency power of $50 \mathrm{~W}$. An etching time is typically $90 \mathrm{~s}$. After the dry etch step, the $150 \mathrm{~nm}$ thick Al layer is sputtered through shadow mask 3 under the same experimental conditions as that for the bottom metallization.

An outgoing inspection of the PV module includes the visual inspection using an optical microscope, and electrical characterization that included the measurements of current-voltage (I-V) characteristics under AM1.5 illumination conditions for each section of 18 cells. I-V curves were analyzed to deduce the solar cell characteristics.

\section{Device modelling and characterization}

To optimize the device design, two-dimensional simulation was performed. Figure $2 a$ illustrates the proposed electrical model, where the individual cell is divided into equidimensional rectangular subcells with a node at the center of each sub-cell. An 
Fig. 2. (a) Simulated cell with uniform mesh and equivalent circuit of the subcell. (b) Potential distribution across the emitter at a biasing voltage of $0.71 \mathrm{~V}$.
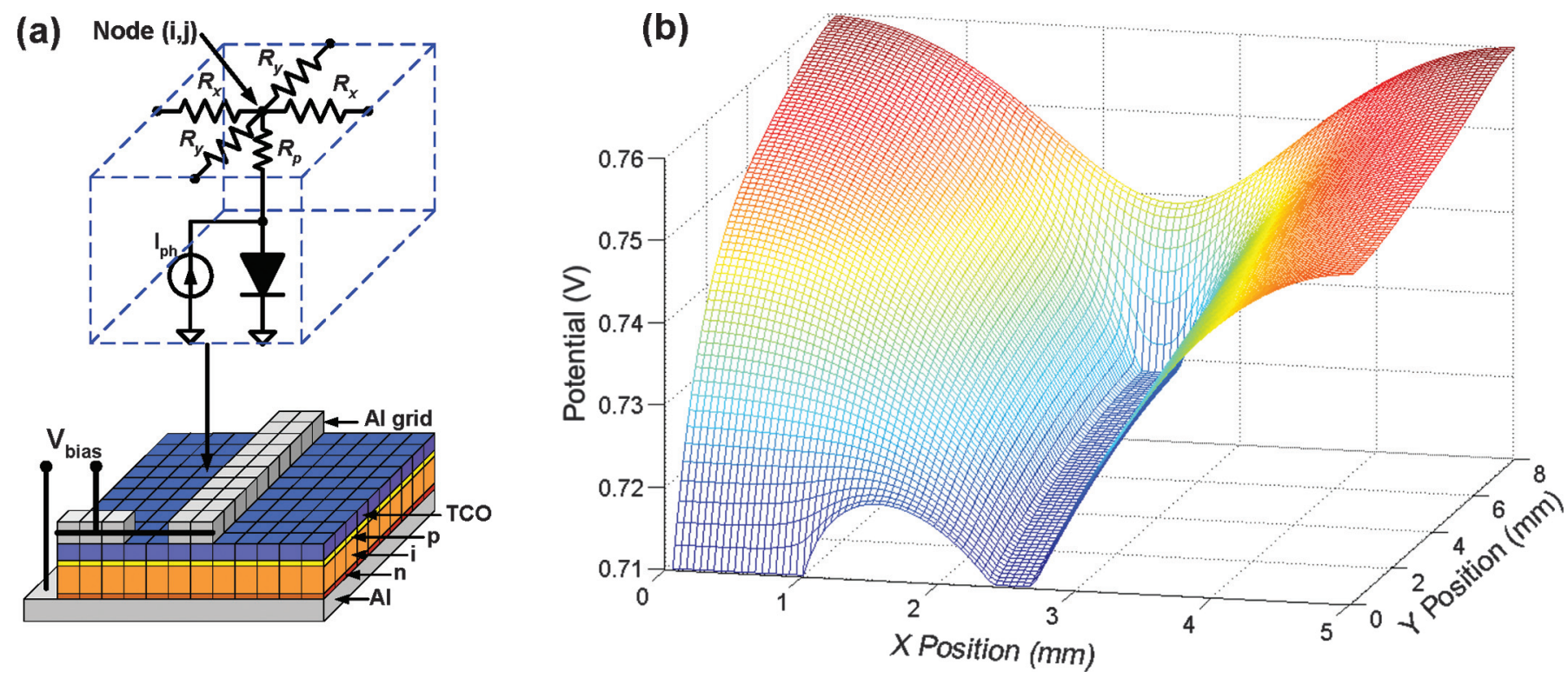

equivalent circuit of the sub-cell includes a diode, a current source representing current generation in the n-i-p structure, a resistor, $R_{\mathrm{p}}$, including both the resistance of the p-layer and contact resistance of the $\mathrm{p} / \mathrm{ZnO} \mathrm{Al}$ interface, and resistors $R_{x}$ and $R_{y}$ representing the top metallization and (or) transparent electrode, respectively. Note that the sheet resistance of the bottom metal is at least two orders of magnitude lower than that of the $\mathrm{ZnO}$ :Al layer, and this series resistance component is not taken into account. Nodes at the front edge of the $\mathrm{Al}$ grid are defined as the current sink in this model with the boundary condition being the applied bias. We used HSPICE simulator to perform calculations, while MATLAB was used to form the input file, to readout data from the output file, and to visualize the results. Input parameters include the dimensions of the cell, coordinates of top metal islands, sheet resistances of the TCO and top metal layers, net series resistance, $R_{\mathrm{p}}$, and parameters of the diode and current source elements. In particular, the diode forward current is

$I=J_{0} L_{x} L_{y}\left[\exp \left(\frac{q V}{n k T}\right)-1\right]$

where $J_{o}$ is the saturation current density, $L_{x}$ and $L_{y}$ are the subcell dimensions in the direction $X$ or $Y, q$ is the elementary charge, $n$ is the photodiode ideality factor, $k$ is Boltzmann's constant, and $T$ is the temperature. The output of the current source is

$I_{\mathrm{ph}}=J_{\mathrm{ph}} L_{x} L_{y}$

where $J_{\mathrm{ph}}$ is the photocurrent density. For p-i-n cells, the $J_{\mathrm{ph}}$ is a bias voltage dependent function [9]

$J_{\mathrm{ph}}=J_{\mathrm{ph}, 0} \frac{V-V_{\mathrm{bi}}}{V_{r}}\left[1-\exp \left(\frac{V_{\mu}}{V-V_{\mathrm{bi}}}\right)\right]$

$V_{\mu}=\frac{d_{\mathrm{i}}^{2}}{\mu \tau}$ where $J_{\mathrm{ph}, 0}$ is the photocurrent, $V_{\mathrm{bi}}$ the built-in voltage, $d_{\mathrm{i}}$ the i-layer thickness, and $\mu \tau$ the mobility-lifetime product also known as the range of the carriers (i.e., distance drifted before capture per unit field). Parameters $J_{0}, n, R_{\mathrm{p}}, V_{\mathrm{bi}}, V_{\mu}$, and $J_{\mathrm{ph}, \mathrm{o}}$ were deduced from $I-V$ characteristics of individual cells in the dark and under illumination.

Figure $2 b$ shows simulated potential distribution across the emitter at the bias voltage of $0.71 \mathrm{~V}$. Input parameters used for simulation are $J_{\mathrm{o}}=10^{-12} \mathrm{~A} / \mathrm{cm}^{2}, n=1.5, V_{\mathrm{bi}}=1.1 \mathrm{~V}, V_{\mu}=0.1 \mathrm{~V}, R_{\mathrm{p}}=$ $1.5 \Omega \mathrm{cm}^{2}$, and $J_{\mathrm{ph}, 0}=9 \mathrm{~mA} / \mathrm{cm}^{2}$. Here, the voltage drop across the Al finger is $10 \mathrm{~V}$ and voltage variation across the transparent electrode is up to $50 \mathrm{mV}$ at $0.3 \Omega / \mathrm{sq}$ and $180 \Omega /$ sq sheet resistances of the respective layers. Joule losses in the Al finger and $\mathrm{ZnO}: \mathrm{Al}$ electrode are 22 and $61 \mu \mathrm{W}$, respectively.

The thickness of the transparent electrode is optimized later to minimize the optical and electrical losses. Reflection minimum of TCO coating at a targeting wavelength, $\lambda_{0}$, is at discrete values of film thicknesses

$d_{\mathrm{TCO}}=\frac{\lambda_{0}(2 m+1)}{4 n_{\mathrm{r}}}$

where $n_{\mathrm{r}}$ is the refractive index at $\lambda_{0}$, and $m=0,1, \ldots$ We have performed the device simulation at $\mathrm{ZnO}$ :Al thicknesses that correspond to the first four reflection minima at $\lambda_{0}=460 \mathrm{~nm}$. To take into account the absorption loss within the transparent electrode, $J_{\mathrm{ph}, 0}$ is calculated for the given film thicknesses using the absorption coefficient of $\mathrm{ZnO}$ :Al measured in the visible to near-infrared spectral range. Figure 3 shows the calculated Joule losses in the Al and $\mathrm{ZnO}$ :Al top layers, conversion efficiency, $E_{\mathrm{ff}}$, and fill factor, FF, versus the transparent electrode thickness. The increase in the ZnO:Al layer thickness leads to the reduction of Joule losses in the emitter and to FF enhancement due to the decreasing series resistance. However, the conversion efficiency reaches a peak value at a thickness of $3 \lambda_{0} / 4 n_{\mathrm{r}}$, then it decreases because of increasing absorption loss. Based on this modeling result, the thickness of $\mathrm{ZnO}: \mathrm{Al}$ in our device is $180 \mathrm{~nm}$. 
Fig. 3. Joule losses in the $\mathrm{ZnO}: \mathrm{Al}$ and $\mathrm{Al}$ top layers, conversion efficiency and fill factor versus $\mathrm{ZnO}$ :Al thickness.

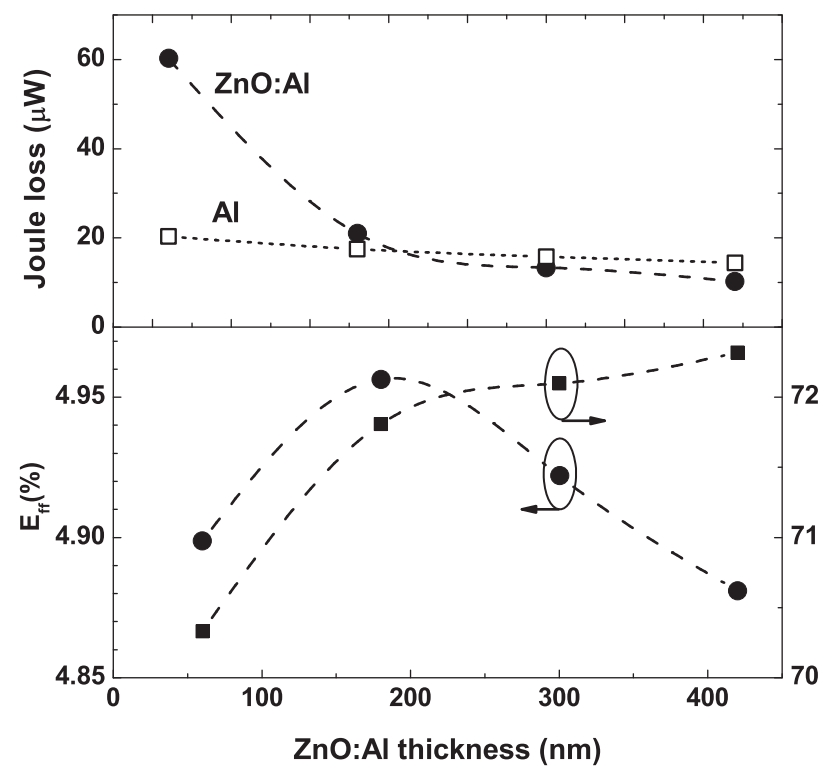

Fig. 4. Joule losses in the $\mathrm{Al}$ and $\mathrm{ZnO}: \mathrm{Al}$ top layers, conversion efficiency and fill factor versus Al-layer sheet resistance.

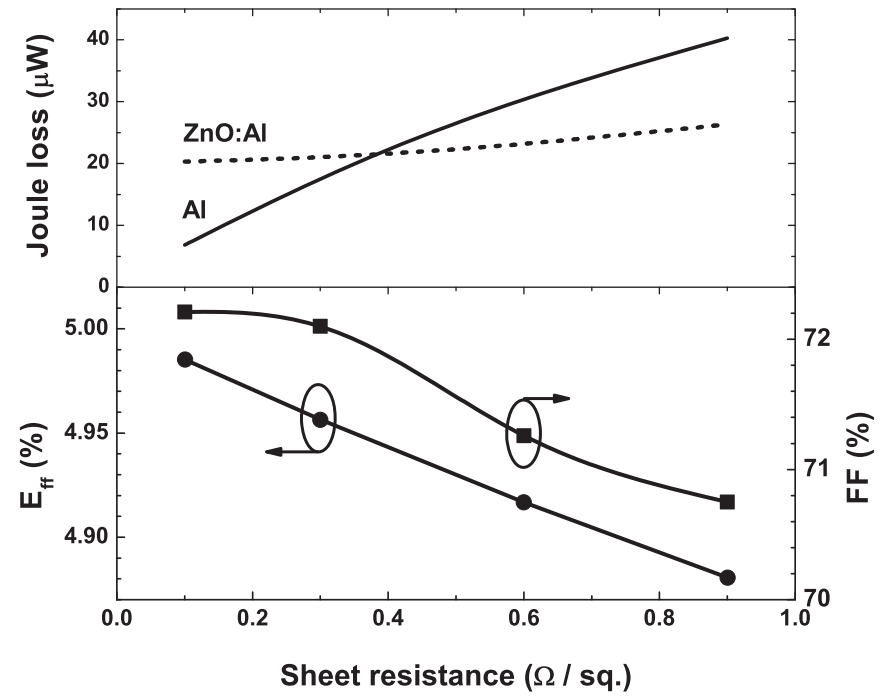

We have also analyzed the impact of the metal grid on the output characteristics. Figure 4 shows the $E_{\mathrm{ff}}$ and FF along with Joule losses in the emitter as a function of the Al-layer thickness. Apparently the metal grid resistance must be lower than the resistance of the transparent electrode to minimize the Joule losses. For the optimized $\mathrm{ZnO}$ :Al electrode with $60 \Omega /$ sq sheet resistance, the metal sheet resistance has to be below $0.4 \Omega / \mathrm{sq}$. The $150 \mathrm{~nm}$ thick Al-layer with $\sim 0.25 \Omega /$ sq is chosen for our devices as a tradeoff between the sputtering time and device performance.
Fig. 5. $I-V$ characteristics of the module section (18 individual cells connected in series) under AM1.5 conditions.

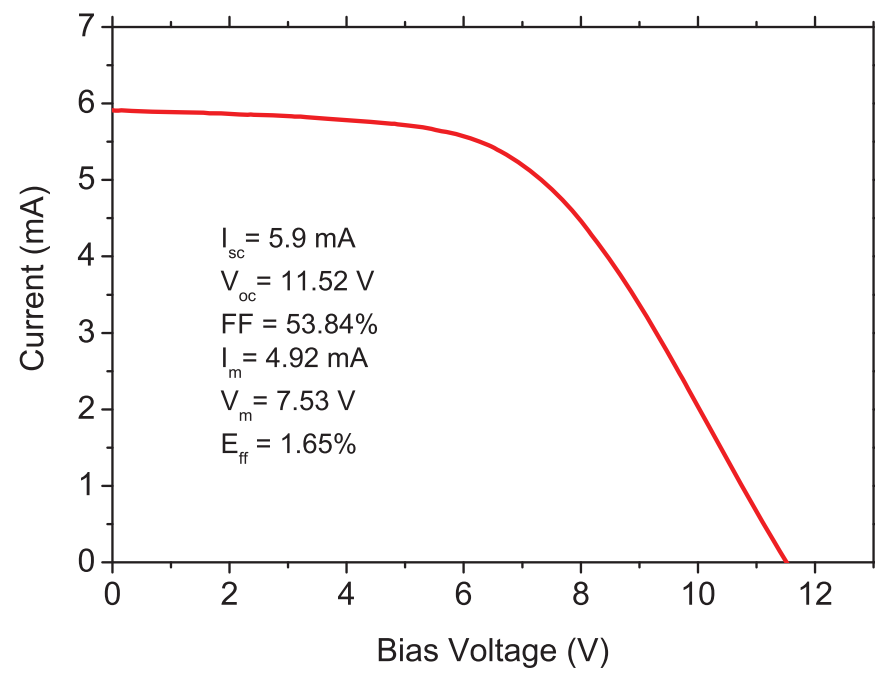

Figure 5 shows a typical $I-V$ curve of the module section composed of 18 cells under AM1.5 illumination conditions. The open circuit voltage and fill factor here are lower than they are supposed to be because of resistive shunts in some cells in the module (about 15\% of all cells for $0.8 \mathrm{~cm}^{2}$ cell size in our laboratory).

\section{Conclusion}

We have fabricated monolithic a-Si:H PV modules on the $100 \mu \mathrm{m}$ thick polyethylene-naphtalate substrate using a $150{ }^{\circ} \mathrm{C}$ deposition process for a-Si:H films. To optimize the device design, two-dimensional simulation was performed. The proposed SPICE model takes into account the performance characteristics of the $\mathrm{n}$-i-p structure and distributed resistances of the transparent electrode and top metal grid. The results suggest that the threequarter wavelength thickness is optimal for the $\mathrm{ZnO}$ :Al electrode, while $150 \mathrm{~nm}$ thick $\mathrm{Al}$ is sufficient for the metal grid. The performance characteristics of the PV module are below the simulation results because of the presence of individual cells with shunts.

\section{References}

1. Y. Ichikawa, T. Yoshida, T. Hama, H. Sakai, and K. Harashima. Sol. Energy Mater. Sol. Cells, 66, 107 (2001). doi:10.1016/S0927-0248(00)00163-X.

2. M.B. Schubert and R. Merz. Philos. Mag. 89, 2623 (2009). doi:10.1080/ 14786430903147122.

3. K. Beernink, S. Guha, et al. NASA/CP - 214494, 54 (2007).

4. J. Poortmans and V. Arkhipov. Thin Film Solar Cells Fabrication, Characterization and Applications. John Wiley \& Sons Ltd. 2006. Ch. 5.

5. T. Söderström, F.-J. Haug, V. Terrazzoni-Daudrix, and C. Ballif. J. Appl. Phys. 103, 114509 (2008). doi:10.1063/1.2938839.

6. K.H. Kim, Y. Vygranenko, D. Striakhilev, M. Bedzyk, J.H. Chang, A. Nathan, T.C. Chuang, G. Heiler, and T. Tredwell. J. Non-Crystal. Solids, 354, 2590 (2008). doi:10.1016/j.jnoncrysol.2007.09.042.

7. J.K. Rath, M. Brinza, Y. Liu, A. Borreman, and R.E.I. Schropp. Sol. Energy Mater. Sol. Cell, 94, 1534 (2010). doi:10.1016/j.solmat.2010.01.013.

8. F.-J. Haug, T. Söderström, M. Python, V. Terrazzoni-Daudrix, X. Niquille, and C. Ballif. Sol. Energy Mater. Sol. Cell, 93, 884 (2009). doi:10.1016/j.solmat.2008. 10.018.

9. E.V. Johnson, F. Dadouche, M.E. Gueunier-Farret, J.P. Kleider, and P. Roca i Cabarrocas. Phys. Status Solidi A, 207(3), 691(2010). doi:10.1002/pssa. 200982723. 
Copyright of Canadian Journal of Physics is the property of Canadian Science Publishing and its content may not be copied or emailed to multiple sites or posted to a listserv without the copyright holder's express written permission. However, users may print, download, or email articles for individual use. 